Int. J. Dev. Biol. 48: 307-317 (2004)

Original Article

\title{
Terminal differentiation of palatal medial edge epithelial cells in vitro is not necessarily dependent on palatal shelf contact and midline epithelial seam formation
}

\author{
TOSHIYA TAKIGAWA ${ }^{*, 1}$ and KOHEI SHIOTA ${ }^{1,2}$ \\ ${ }^{1}$ Department of Anatomy and Developmental Biology and ${ }^{2}$ Congenital Anomaly Research Center, Kyoto University Graduate School of \\ Medicine, Kyoto, Japan
}

\begin{abstract}
During fusion of the mammalian secondary palate, it has been suggested that palatal medial edge epithelial (MEE) cells disappear by means of apoptosis, epithelial-mesenchymal transformation (EMT) and epithelial cell migration. However, it is widely believed that MEE cells never differentiate unless palatal shelves make contact and the midline epithelial seam is formed. In order to clarify the potential of MEE cells to differentiate, we cultured single (unpaired) palatal shelves of ICR mouse fetuses by using suspension and static culture methods with two kinds of gasmixtures. We thereby found that MEE cells can disappear throughout the medial edge even without contact and adhesion to the opposing MEE in suspension culture with $95 \% \mathrm{O}_{2} / 5 \% \mathrm{CO}_{2}$. Careful examination of MEE cell behavior in the culture revealed that apoptosis, EMT, and epithelial cell migration all occurred at various stages of MEE cell disappearance, including the transient formation and disappearance of epithelial triangles and islets. In contrast, MEE cells showed poor differentiation in static culture in a $\mathrm{CO}_{2}$ incubator. Furthermore, mouse and human amniotic fluids were found to prevent MEE cell differentiation in the cultured single palatal shelf, although paired palatal shelves fused successfully even in the presence of amniotic fluid. We therefore conclude that terminal differentiation of MEE cells is not necessarily dependent on palatal shelf contact and midline epithelial seam formation, but such MEE cell differentiation appears to be prevented in utero by amniotic fluid unless palatal shelves make close contact and the midline epithelial seam is formed.
\end{abstract}

KEY WORDS: secondary palate, medial edge epithelial cell, apoptosis, epithelial-mesenchymal transformation, epithelial cell migration, amniotic fluid

\section{Introduction}

The formation of the mammalian secondary palate requires several developmental steps, including growth, elevation, and midline fusion of the palatal shelves (Ferguson, 1988). During the fusion of palatal shelves, a midline epithelial seam is formed following the contact and adhesion of the medial edge epithelial (MEE) cells of the bilateral palatal shelves. Subsequently, the midline epithelial seam rapidly thins and undergoes disruption, concomitantly with the disruption of the underlying basement membrane. 'Epithelial triangles' and 'epithelial islets' are formed transiently along the disrupting midline seam and later disappear to bring about mesenchymal confluence across the secondary palate.

Many investigations have focused on the mechanisms underlying the disappearance of MEE cells during palatal fusion. Earlier studies provided ultrastructural evidence for the occurrence of programmed cell death (PCD) in disappearing MEE cells such as the presence of autophagic vacuoles, lysosomes and macrophages (Shapiro and Sweney, 1969; Smiley, 1970; Smiley and Koch, 1975). The mode of cell death was shown to be apoptosis by cytochemical evidence of apoptotic DNA fragmentation (Mori et al., 1994; Taniguchi et al., 1995; Martínez-Álvarez et al., 2000; Cuervo et al., 2002; Cuervo and Covarrubias, 2004). On the other hand, Fitchett and Hay (1989) reexamined the process of palatal fusion in rats and observed the occurrence of epithelial-mesenchymal transformation (EMT) in the disappearing midline epithelial seam. They concluded that basal MEE cells never die but undergo EMT and that PCD is restricted to the periderm (super-

Abbreviations used in this paper:EMT, epithelial-mesenchymal transformation; MEE, medial edge epithelium; PCD, programmed cell death

*Address correspondence to: Dr. Toshiya Takigawa. Department of Anatomy and Developmental Biology, Kyoto University Graduate School of Medicine. Kyoto 606-8501, Japan. Fax: +81-75-751-7529. e-mail address: takigawa@cac.med.kyoto-u.ac.jp 
ficial MEE) cells when the cells are trapped in the midline seam. Fitchett and Hay (1989) and Shuler et al. (1991) characterized the EMT of MEE cells by the change of cellular intermediate filaments. Although MEE cells express cytokeratin before palatal shelf contact, they express vimentin simultaneously with cytokeratin at the time of midline seam disruption and only vimentin after palatal fusion. In addition to such cytoskeletal changes, labeling of MEE cells with fluorescent dyes before palatal shelf contact revealed that they remained in the mesenchyme after palatal fusion (Shuler et al., 1991; 1992; Griffith and Hay, 1992). However, Carette and Ferguson (1992) failed to observe EMT and PCD in a similar cell tracing study and concluded that epithelial cell migration toward the nasal and oral epithelia is the mechanism responsible for MEE cell disappearance during palatal fusion. Although Mori et al. (1994) and Martínez-Álvarez et al. (2000) claimed that PCD, EMT, and epithelial cell migration are all involved in MEE cell disappearance, recently Cuervo et al. (2002) and Cuervo and Covarrubias (2004) failed to observe EMT in fusing palates in vitroand claimed that MEE cells disappear mainly by PCD during palatal fusion. Thus, the actual MEE cell fates are still inconclusive and await further clarification.

In addition, it remains unclear whether palatal shelf contact and midline seam formation are required for MEE cell differentiation. Some previous studies showed that MEE cells could partially degenerate when palatal shelves were separated and cultured singly in vitro(Smiley and Koch, 1972, 1975; Dixon and Ferguson, 1992). However, Griffith and Hay (1992) failed to observe such MEE cell disappearance in the palatal shelves cultured singly and concluded that formation of the midline epithelial seam is indispensable for inducing EMT of basal MEE cells. Since their paper, no investigators have shown the occurrence of autonomous MEE cell disappearance in single (unpaired) palatal shelf cultures. Therefore, it seems to be widely accepted that MEE cells differentiate dependently on palatal shelf contact and midline seam formation. Consistent with this hypothesis, in cases of cleft palate, there has been no report that MEE cells disappeared from the medial edge of unfused palatal shelves.

As mentioned above, most previous hypotheses concerning mammalian palatogenesis were drawn from in vitrostudies using rodent fetal palates. Although palate organ cultures enable various experiments which are impossible in utero, they sometimes produce conflicting results. Palate culture methods reported thus far can be largely divided into the static culture method using a $\mathrm{CO}_{2}$ incubator (Pourtois, 1966, 1968; Smiley and Koch, 1971, 1972, 1975; Dixon and Ferguson, 1992; Griffith and Hay, 1992; Martínez-Álvarez et al., 2000; Cuervo et al., 2002; Cuervo and Covarrubias, 2004) and the suspension culture method with rolling bottles (Shiota et al., 1990; Brown et al., 2002). In those cultures, some fundamental questions remain such as: (1) Can MEE cells grow and differentiate fully as in utero? (2) Does the differentiation pattern of MEE cells in vitro really simulate that occurring in utero? (3) Do in vitro and in utero environments influence MEE cell differentiation differently? These questions should be answered to reach reliable conclusions, but no previous studies have answered them.

The present study aimed to clarify the potential of MEE cells to differentiate in vitro. To investigate the crude ability of MEE cells to differentiate, we designed in vitroexperiments using the single palatal shelf of the ICR mouse fetus, because the MEE cells of cultured single shelves can be examined not only histologically but also by direct observation with scanning electron microscopy
Single shelf explants
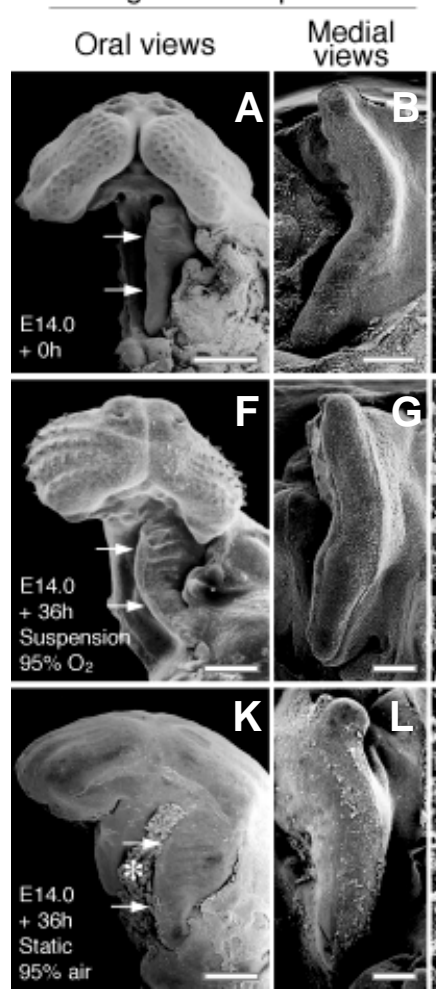

Cell morphology

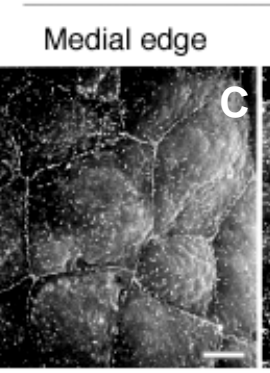

$$
\text { Oral epithelia }
$$
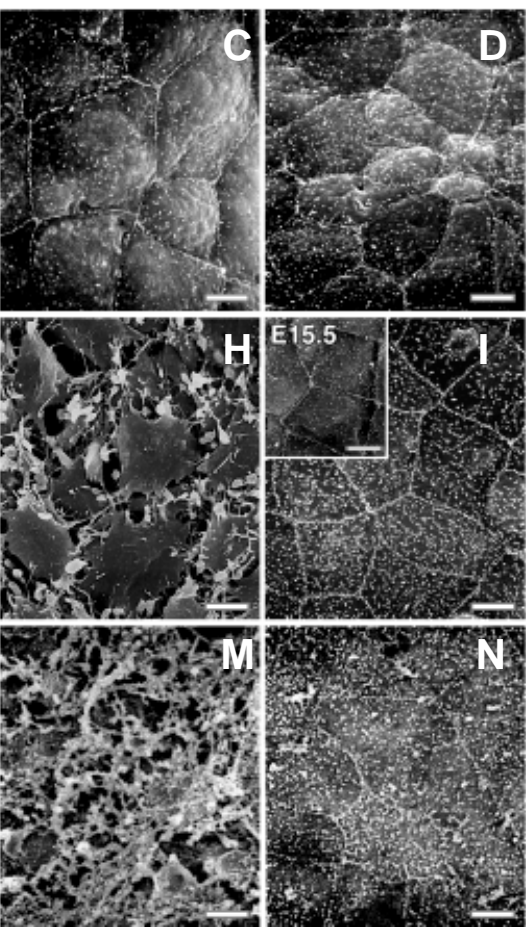

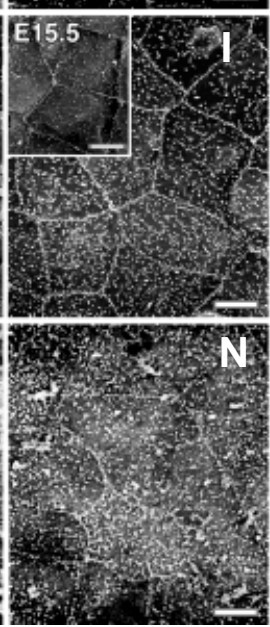

Nasal epithelia
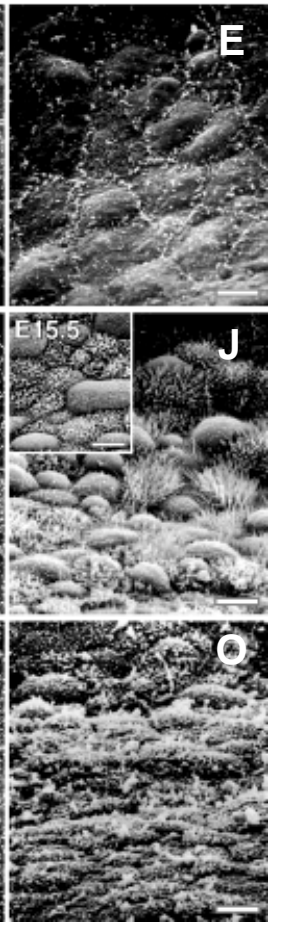

Fig. 1. SEM images showing single palatal shelves and the cell morphology of medial edges and oral and nasal epithelia before and after $\mathbf{3 6}$ hours of culture. (A-E) The E14.0 single palatal shelf and high-magnifications of each epithelium before culture. In order from the left, oral and medial views of the single shelf explants, and the cell morphology of the medial edge and oral and nasalepithelia, respectively. (F-J) Corresponding images of (A-E) after 36 hours of suspension culture with $95 \% \mathrm{O}_{2} / 5 \% \mathrm{CO}_{2}$ respectively. Insets in $(I, J)$ show the oral and nasal epithelia of E15.5 palates, respectively. (K-O) Corresponding images of (A-E) after 36 hours of static culture with $95 \%$ air $15 \% \mathrm{CO}_{2}$ respectively. In oral views of the single shelf, its anterior direction faces up in each image. In medial views, its anterior direction faces up in each image, and the nasal side of the shelf faces right and the oralside faces left, respectively. Arrows in $(A, F, K)$ indicate the medial edge of the single palatal shelf. The asterisk in (K) marks the necrotic tissues pushed out from the interior of the explants due to gravity. Note that the oraland nasal epithelia showed poor differentiation and the medial edge cells became degenerative when the single palatal shelf was cultured for 36 hours by static culture with $95 \%$ air $/ 5 \% \mathrm{CO}_{2}$ in a $\mathrm{CO}_{2}$ incubator (K-O). Scalebars: $(A, F, K) 500 \mu m ;(B, G, L)$ $100 \mu \mathrm{m},(C-E, H-J, M-O) 5 \mu \mathrm{m}$. 
(SEM). We compared the effects of static and suspension culture methods with two kinds of gas-mixtures on MEE cell differentiation. Furthermore, we examined the effects of amniotic fluid on MEE cell differentiation as well as palatal fusion in vitro, because amniotic fluid seemed to be an essential component of the intrauterine environment of MEE cells. Our study showed that the ability of MEE cells to differentiate in vitro varies with the palate culture method and that MEE cell differentiation is influenced by amniotic fluid.

\section{Results}

\section{Effects of suspension and static cultures with two kinds of gas-mixtures on growth and differentiation of palatal tissues in vitro}

In normal palate development in ICR mice, palatal shelves usually elevate above the tongue by E14.0, but they do not make contact with each other until around E14.3. Although the medial edge region of the $\mathrm{E} 14.0$ palatal shelf was not clearly distinguishable from the oral and nasal epithelia (Fig. $1 \mathrm{~A}, \mathrm{~B}$ ), periderm cells of the medial edge slightly bulged and firmly adhered with each other (Fig. 1C). Histologically, the MEE consisted of the flat periderm (superficial MEE) cells and cuboid basal MEE cells, though the periderm cells were sometimes artifactually missing in the sections of $5 \mu \mathrm{m}$ thickness (Fig. 2A). The oral epithelium consisted of immature squamous cells (Fig. 1D). The nasal epithelium was not yet differentiated into the respiratory epithelium (Fig. $1 \mathrm{E})$. However, when the single palatal shelf was cultivated for 36 hours in suspension culture with $95 \% \quad \mathrm{O}_{2} / 5 \% \quad \mathrm{CO}_{2}$, the MEE became distinguishable from the oral and nasal epithelia by a clear boundary (Fig. 1 F,G). In high-magnification images, it was clear that multipolar fibroblast-like cells were present on the medial edge instead of epithelial cells (Fig. $1 \mathrm{H}$ ). Concurrently, oral epithelial cells differentiated into mature, pavement-like squamous cells (Fig. 1I) and nasal epithelial cells differentiated into ciliated columnar cells and non-ciliated bulgy cells (Fig. 1J), equivalent to those of E15.5 palates (insets of Fig. $1 \mathrm{I}, \mathrm{J})$. Such complete MEE cell disappearance was always observed in every single palatal shelf after 36 hours of suspension culture with $95 \% \mathrm{O}_{2} / 5 \% \mathrm{CO}_{2}$ (Table $1)$. When the single shelves were cultivated for 36 hours of suspension culture with $95 \%$ air $/ 5 \% \mathrm{CO}_{2}$ or static culture with $95 \%$ $\mathrm{O}_{2} / 5 \% \mathrm{CO}_{2}$, MEE cells could disappear but their complete disappearance occurred much less frequently than in suspension cultures with $95 \% \mathrm{O}_{2} / 5 \% \mathrm{CO}_{2}$ (Fig. $2 \mathrm{C}, \mathrm{D}$ and Table 1). In contrast,

TABLE 1

\section{NUMBER OF SINGLE PALATAL SHELVES SHOWING MEE CELL DISAPPEARANCE AT 36 HOURS OF STATIC AND SUSPENSION CULTURES}

\begin{tabular}{lrrr} 
MEE cell disappearance & Complete & Partial & \multicolumn{1}{c}{ No } \\
\hline Culture method (gas-mixtures used) & & & \\
Suspension $\left(95 \% \mathrm{O}_{2} / 5 \% \mathrm{CO}_{2}\right)$ & $221 / 221(100 \%)$ & $0 / 221(0 \%)$ & $0 / 221(0 \%)$ \\
Suspension $\left(95 \%\right.$ air $\left./ 5 \% \mathrm{CO}_{2}\right)$ & $9 / 16(56 \%)$ & $7 / 16(44 \%)$ & $0 / 16(0 \%)$ \\
Static $\left(95 \% \mathrm{O}_{2} / 5 \% \mathrm{CO}_{2}\right)$ & $8 / 15(53 \%)$ & $7 / 15(47 \%)$ & $0 / 15(0 \%)$ \\
Static $\left(95 \%\right.$ air $\left./ 5 \% \mathrm{CO}_{2}\right)$ & $0 / 17(0 \%)$ & $6 / 17(35 \%)$ & $11 / 17(65 \%)$ \\
\hline
\end{tabular}

Note. MEE cell disappearance was determined by either SEM or histology. 'Complete' includes the case that a small number of epithelial islets were observed. 'Partial' indicates all the cases that MEE cell disappearance occurred but did not extend to the entire medial edge.
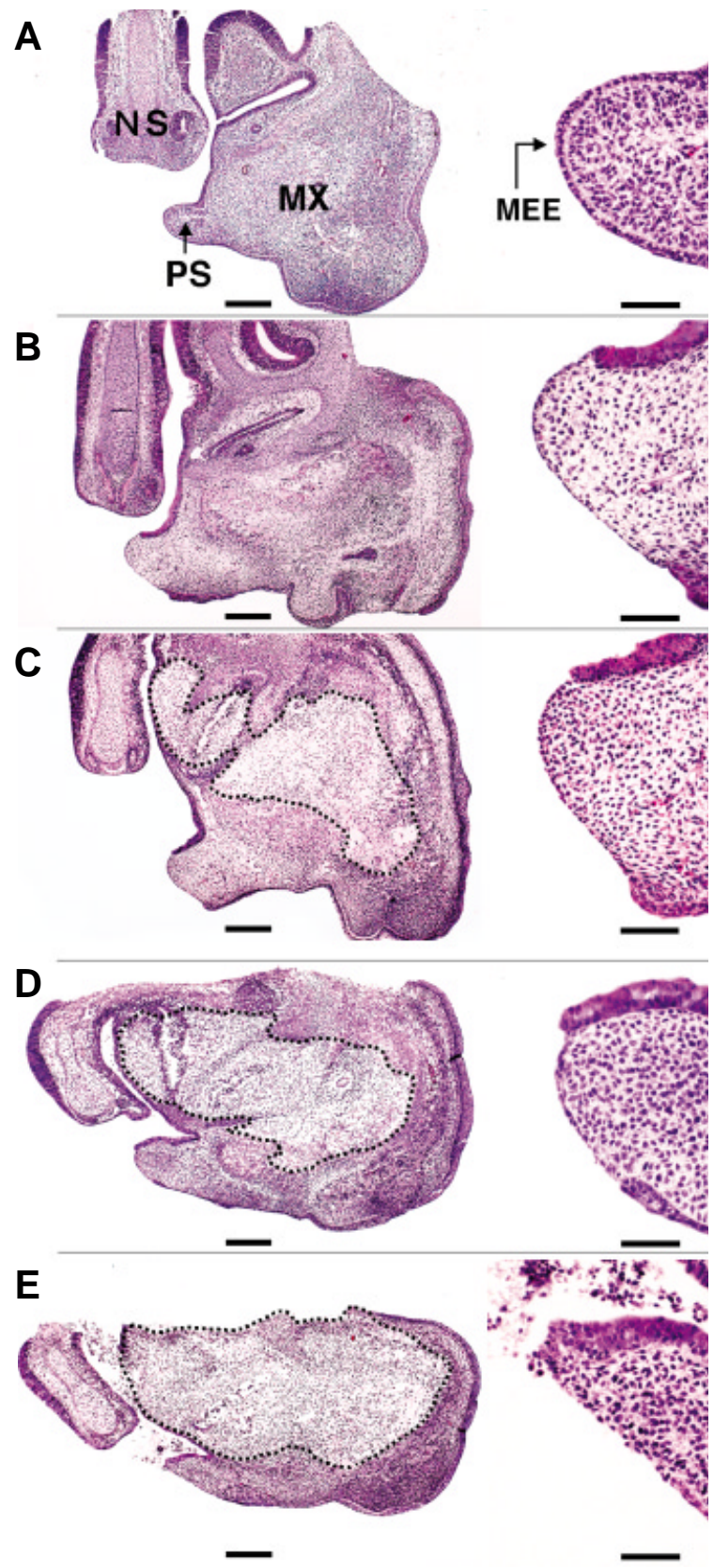

Fig. 2. The histology of the single palatal shelf explants before and after culture for $\mathbf{3 6}$ hours. Sections of the explants were stained with hematoxylin and eosin. The apical portion of each palatal shelf was magnified and shown to the right, respectively. (A) A single palatal shelf of an E14.0 ICR mouse fetus at the beginning of culture. After 36 hours of suspension culture with (B) $95 \% \mathrm{O}_{2} / 5 \% \mathrm{CO}_{2}$ and (C) $95 \%$ air $/ 5 \% \mathrm{CO}_{2}$. After 36 hours of static culture with (D) $95 \% \mathrm{O}_{2} / 5 \% \mathrm{CO}_{2}$ and (E) $95 \%$ air/ $5 \% \mathrm{CO}_{2}$. Abbreviations: PS, palatal shelf; NS, nasal septum; MX, maxilla; MEE, medial edge epithelium. Although MEE cells were present at the tip of the E14.0 single shelf before culture (A), they disappeared after 36 hours in suspension culture with $95 \% \mathrm{O}_{2} / 5 \% \mathrm{CO}_{2}(\mathrm{~B})$ or with $95 \%$ air $/ 5 \% \mathrm{CO}_{2}$ (C), and in static culture with $95 \% \mathrm{O}_{2} / 5 \% \mathrm{CO}_{2}(D)$. In static culture with 95\% air / $5 \% \mathrm{CO}_{2}$, MEE cells sometimes disappeared at the oral side, where the cells had touched the air-medium interface during culture (E). Dashed lines in (C-E) encircle non-physiological necrotic tissues observed. Scale bars: (A-E) $100 \mu \mathrm{m}$; in magnified images of the medial edge, $50 \mu \mathrm{m}$. 
MEE cells largely persisted or degenerated in static culture for 36 hours with $95 \%$ air $/ 5 \% \mathrm{CO}_{2}$ in a standard $\mathrm{CO}_{2}$ incubator (Figs. $1 \mathrm{~L}-\mathrm{N}, 2 \mathrm{E}$, and Table 1). Oral and nasal epithelial cells did not differentiate fully (Fig. $1 \mathrm{~N}, \mathrm{O}$ ). Even when the shelves were cultivated for up to 72 hours in the static culture, complete MEE cell disappearance was never observed and the cells became more degenerative (data not shown). Although nonphysiological massive necrosis was always observed within the cultured explants, it was minimal in suspension cultures with $95 \% \mathrm{O}_{2} / 5 \% \mathrm{CO}_{2}$ and was maximal in static cultures with $95 \%$ air/ $5 \% \mathrm{CO}_{2}$ (Compare Fig. $2 \mathrm{~B}$ and 2E). In addition, deformation of the explants due to gravity was always observed after static culture, although it never took place in suspension culture (Compare Figs. 1F, 2 B,C and 1K, 2 D,E). These results suggest that MEE cell disappearance in suspension cultures with $95 \% \quad \mathrm{O}_{2} / 5 \%$ $\mathrm{CO}_{2}$ is closely associated with the terminal differentiation of MEE cells, because palatal tissues in the culture remained totally healthy and oral and nasal epithelial cells followed the same normal differentiation patterns as in utero. On the other hand, in the static organ culture in a $\mathrm{CO}_{2}$ incubator, the differentiation of palatal epithelia was always incomplete and MEE cell degeneration was more evident than in suspension culture, indicating that conventional static culture methods are not suitable for supporting the growth and differentiation of palatal tissues in vitro.

\section{MEE cells of the single palatal shelf can undergo terminal differentiation in suspension culture}

In order to investigate how MEE cells disappear from the medial edge of the single palatal shelf in suspension culture with $95 \% \quad \mathrm{O}_{2} / 5 \% \quad \mathrm{CO}_{2}$, we harvested them at various time intervals during culture and examined the process of MEE cell disappearance morphologically and histologically.

At the beginning of culture, periderm cells of the medial edge were intact, as judged by SEM morphology (Figs. 1C, 3A). Histologically, all the palatal epithelia were positive for cytokeratin immunoreactivity (Fig. 4A) and the basement membrane underlying the palatal epithelia was intact (Fig. 4A). No dead cells
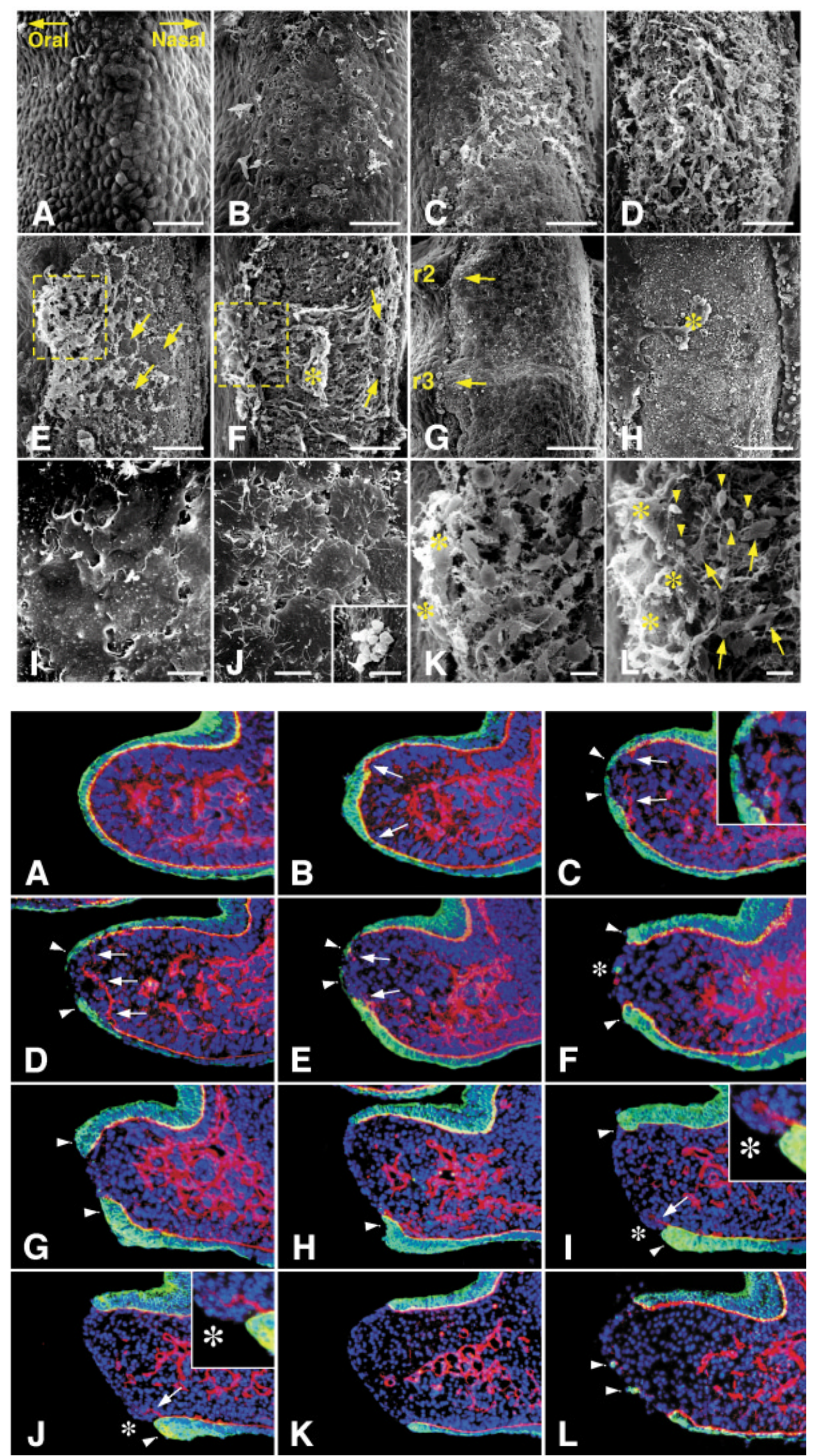
Fig. 3 (Left, Top). Morphological sequence of MEE cell differentiation in suspension culture of the single palatal shelf. SEM images shows the MEE cells at E14.0 (A) and after 16 hours (B,I), 18 hours (C,J), 20 hours (D), 24 hours (E,F,K,L) and 36 hours (G,H) of culture. (I-L) Higher magnifications show selected portions of $(B, C, E, F)$, respectively. (A-D, I,J) Periderm cells of the MEE at E14.0 (A) became flattened and began to be dissociated from each other by 16 hours of culture (B,I). Most of the cells developed numerous filopodia by 18 hours $(C, J)$ and became fibroblast-like by 20 hours of culture (D), while some cells underwent apoptosis (inset in J). (E,F,K,L) After the morphological changes shown in (B-D), the fibroblast-like periderm cells migrated toward the oral side ( $K, L=$ boxed regions in $E, F$, respectively) and nasal side (arrows in F), and basal MEE cells thereby began to be exposed to the medial edge surface (arrows in E). The asterisk in F marks a transiently formed epithelial islet. Such islets were observed occasionally. Although the cells migrating toward the oral side showed a fibroblast-like appearance (K), they later divided into the two populations (L). One entered into the oral epithelium (asterisks in $K, L$ ), taking the debris of dead cells, and another remained near the oral end of the medial edge (arrows in L). Arrowheads in (L) indicate cells undergoing apoptosis. (G) The appearance of the medial edge after 36 hours of culture. Arrows indicate the migratory stream of medial edge cells toward the medial ends of the second ( $r 2$ ) and third (r3) palatal rugae. Asterisk in (H) indicates rare persistent epithelial islets after 36 hours of culture. Scale bars: (A-H) 50 $\mu \mathrm{m},(\mathrm{I}-\mathrm{L}) 5 \mu \mathrm{m}$.

Fig. 4 (Left, Bottom). Histological sequence of MEE cell differentiation in suspension culture of the single palatal shelf. All the merged-images show dual immunofluorescence for cytokeratin (FITC) and type IV collagen (TRITC). The total nuclei were stained with Hoechst 33342 . Insets of (C, I, J) are higher magnifications of the transforming MEE cells (C) and the disappearing oral epithelial triangles (I,J) of each section. (A) At the beginning of culture, palatal epithelia, including MEE cells, were all positive for cytokeratin and their basement membrane was intact. (B) After 16 hours of culture, the cytokeratin-positive MEE thickened and its basement membrane was angulated at the nasal and oral ends of the medial edge (arrows). (C-E) After 18 hours of culture, the basal MEE cells began to lose cytokeratin, while pushed and disrupted the underlying mesenchyme (arrows). Concurrently, some of the transforming basal MEE cells underwent apoptosis, as judged by nuclear morphology (inset in C). Cytokeratin-positive periderm cells (arrowheads) began to disappear at the tip of the shelf and the disappearance of them was extended orally (upward) and nasally (downward). (F,G) After 20 hours of culture, the remaining MEE became thickened at the oral and nasal ends of the medial edge (arrowheads in F) and formed epithelial epithelial triangles (arrowheads in G). The asterisk in (F) marks a transitory epithelial islet. (H-J) After 24 hours of culture, the cells forming epithelial triangles gradually lost cytokeratin (asterisks in I,J), followed by the disruption of the basement membrane (arrows in I,J). During the regression of epithelial triangle, the cells gradually lost cytokeratin immunoreactivity but some of them remained healthy, as judged by nuclear morphology (asterisks in insets of I,J). (K,L) After 36 hours of culture, cytokeratin-positive cells usually disappeared from the entire medial edge, as shown in (K). However, persistent epithelial islets were rarely seen after 36 hours of culture (arrowheads in L).

were observed in the MEE, as judged by TUNEL staining (Fig. 5A). However, the periderm of the MEE became flattened and the MEE cells began to be dissociated from each other by 16 hours of culture (Fig. 3 B,I) and subsequently developed numerous filopodia (Fig. $3 \mathrm{C}, \mathrm{J}$ ), while some cells underwent apoptosis (inset in Fig. $3 \mathrm{~J}$ ). In histological sections, the cytokeratin-positive MEE became thickened and its basement membrane was angulated at the oral and nasal ends of the medial edge by 16 hours of culture (Fig. 4B). After the MEE thickening, basal MEE cells lost cytokeratin immunoreactivity and their basement membrane began to be disrupted (Fig. 4 C-E), indicating that the basal MEE cells underwent EMT. However, it is interesting to note that many of the transforming basal MEE cells underwent apoptosis during the disruption of the under-

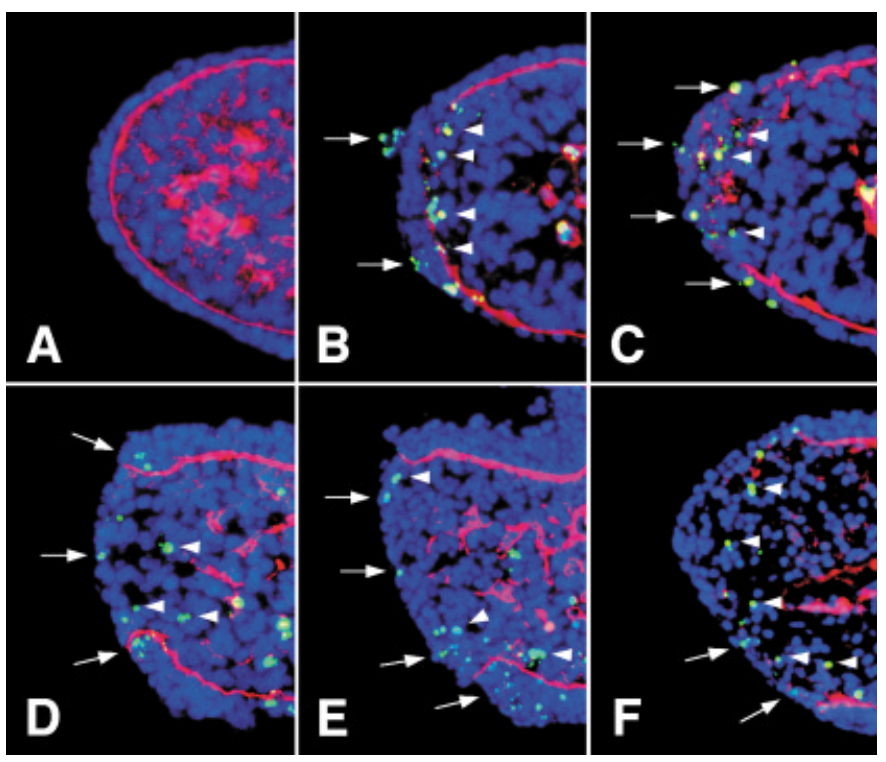

lying basement membrane (Fig. 5 B,C). By 20 hours of culture, the periderm and basal MEE cells lost their epithelial morphology and looked like well-stretched fibroblasts (Fig. 3D). Following such morphological changes, these cells migrated toward the oral and nasal sides and thereby basal MEE cells became exposed to the surface of the medial edge (Fig. 3E). Histologically, loss of cytokeratin in the periderm of the MEE began to occur at the tip of the medial edge (Fig. $4 \mathrm{D}, \mathrm{E}$ ) and subsequently extended both orally and nasally (Fig. 4 F-K), while the adjacent cytokeratin-positive MEE became thickened (Fig. 4 F-J) and later formed epithelial triangles near the oral and nasal ends of the medial edge (Fig. 4 G-I). Occasionally, some periderm and/or basal MEE cells formed epithelial islets on the medial edge (Figs. 3F, 4F). After the formation of epithelial triangles, the cells were not only incorporated into the adjacent epithelia (Fig. $3 F, K, L$ ), but also underwent EMT (Figs. 3 F,L, 4 H-J) or apoptosis (Figs. 3 F,L, 5 D,E). Since periderm cells of the MEE do not undergo EMT (Fitchett and Hay, 1989), it seemed that the transient epithelial triangles comprised both the periderm and basal MEE cells and only the latter under-

Fig. 5. Temporal sequence of MEE cell death and remodeling of the basement membrane in the single palatal shelf in suspension culture. All the merged images show dual staining of TUNEL (FITC) and immunofluorescence for type IV collagen (TRITC). The total nuclei were stained with Hoechst 33342. (A) E.14.0; all the MEE cells were TUNEL-negative at the beginning of culture. (B) After 16 hours of culture, TUNEL-positive apoptotic cells were observed in some periderm cells (arrows) and basal MEE cells (arrowheads). TUNEL-positive basal cells of the MEE were in the mesenchyme subjacent to the disrupted basement membrane (arrowheads). (C) After 18 hours of culture, apoptotic cell death increased in the MEE, but the surviving basal MEE cells took the fragmented basement membrane into the underlying mesenchyme, as is shown in (Fig. 3 C,D). (D,E) After 24 hours of culture, apoptotic cell death still occurred during the regression of the epithelial triangles. (F) After 36 hours of culture, TUNEL-negative cells were present in the place where all the triangles had disappeared. 

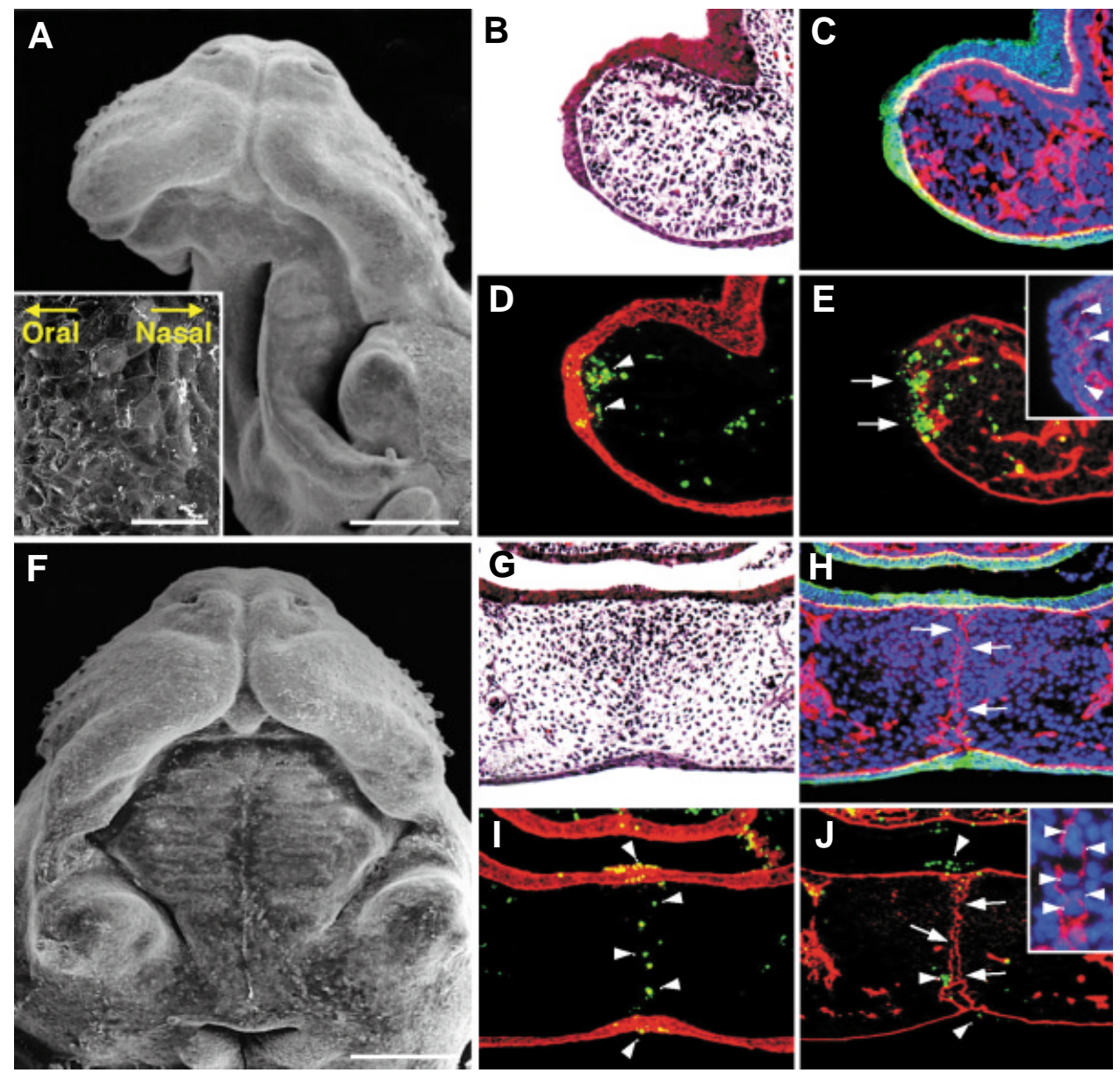

Fig. 6. Effects of mouse amniotic fluid on MEE cells of single and paired palatal shelves after $\mathbf{3 6}$ hours of suspension culture. (A-E) A single palatal shelf cultured for 36 hours with mouse amniotic fluid (A) and the histology thereof (B-E). (F-J) Fused palatal shelves cultured in pairs for 36 hours with mouse amniotic fluid (F) and the histology thereof (G-J). (A,F) SEM images. (B, G) Hematoxilin and eosin-stained palatal tissues. (C,H) Dual immunofluorescence for cytokeratin (FITC) and type IV collagen (TRITC) with nuclear counter-staining with Hoechst 33342. (D,I) Dual staining of TUNEL (FITC) and immunofluorescence for cytokeratin (TRITC). (E,J) Dual staining of TUNEL (FITC) and immunofluorescence for type IV collagen (TRITC). Insets in (E,J) are magnified images of type IV collagen and cell nuclei of the same section, respectively. In the cultured single palatal shelf, periderm of the MEE persisted (inset in A) and cytokeratinpositive MEE was thickened $(C, D)$, while its basement membrane was partially disrupted (arrowheads in inset of E). Scale bars: (A,F) $500 \mu \mathrm{m}$; (inset in A) $50 \mu \mathrm{m}$.

wentEMT. The basement membrane was continually formed at the interface between the cytokeratin-positive and -negative MEE cells, while the original basement membrane was disrupted (Fig. 4 $\mathrm{C}-\mathrm{E}, \mathrm{I}, \mathrm{J})$. At 36 hours of culture, MEE cell differentiation was completed and only fibroblast-like cells were observed on the surface of the medial edge (Figs. $1 \mathrm{G}, \mathrm{H}, 3 \mathrm{G}$ ). Although these cells might comprise both MEE-derived and native mesenchymal cells, they were not distinguishable from each other. Histologically, cytokeratin-positive cells completely disappeared from the medial edge (Fig. 4K) and some TUNEL-positive dead cells remained in the adjacent mesenchyme (Fig. 5F). In addition, our SEM data indicated that some MEE cells, which had migrated toward the oral epithelia, participated in the formation of medial ends of the first to third palatal rugae in the anterior palatal shelf (Fig. $3 G$ ). In very rare cases (1/135 in SEM, 1/86 in histology), epithelial islets persisted even after the MEE cell differentiation (Figs. 3H, 4L). These observations indicate that MEE cells can undergo apoptosis, EMT, and epithelial cell migration in vitroeven without palatal shelf contact and midline seam formation.

Amniotic fluid prevents MEE cell differentiation in the single palatal shelf but does not inhibit palatal fusion

When the single palatal shelf was cultured for 36 hours in suspension culture with mouse amniotic fluid and $95 \% \mathrm{O}_{2} / 5 \%$ $\mathrm{CO}_{2}$, periderm cells remained on the medial edge and retained an epithelial morphology (Fig. 6A). Histologically, the cytokeratin-positive MEE never disappeared but became thickened (Fig. 6B-D, Table 2). In the explants, although many basal MEE cells were sometimes observed to migrate into the subjacent mesenchyme through the partially disrupted basement membrane (Fig. 6C, E), most of them failed to accomplish EMT and underwent apoptosis, as judged by nuclear morphology and TUNEL staining (Fig. $6 \mathrm{D}, \mathrm{E})$. When bilateral palatal shelves were cultured in pairs under the same conditions, palatal fusion always successfully occurred (Fig. 6F-J, Table 2). Although cytokeratin-positive MEE cells always disappeared from the midline of the fusing palate by 36 hours of culture, the complete disruption of the basement membrane in the fusing palate was delayed probably due to the influence of amniotic fluid (Fig. 6H-J) when compared with that in culture without amniotic fluid (Takahara et al., 2004), which appeared to simulate the palatal fusion process in utero (Ferguson, 1988). TUNEL-positive MEE cells were observed in the oral and nasal epithelia and in the mesenchyme near the midline (Fig. 6l, J). However, it should be noted that some transformed MEE cells survived between the fragmented bilateral basement membranes (Inset of Fig. 6J). We confirmed that the human amniotic fluid of 15 and 20 weeks of gestation had similar effects on MEE cell differentiation and palatal fusion (Table 2). Therefore, it is clear that amniotic fluid prevents MEE cell differentiation only when the MEE is directly exposed to the fluid.

\section{Discussion}

In the present study, we showed that MEE cells can undergo terminal differentiation even in the absence of contact and adhesion of the opposing MEE. By using a suspension culture of the single palatal shelf of the E14.0 ICR mouse fetus, we found that MEE cells can always disappear from the entire medial edge by 36 hours of culture. SEM and histological analyses revealed that apoptosis, EMT, and epithelial cell migration all occur in the MEE 
TABLE 2

NUMBER OF SINGLE AND PAIRED PALATAL SHELVES SHOWING MEE CELL DISAPPEARANCE WHEN CULTURED FOR 36 HOURS WITH AMNIOTIC FLUID IN SUSPENSION WITH $95 \% \mathrm{O}_{2} / 5 \% \mathrm{CO}_{2}$

\begin{tabular}{lcc} 
Amniotic fluid used & MEE cell disappearance & No \\
\hline $\begin{array}{c}\text { Single palatal shelves } \\
\text { Mouse amniotic fluids }\end{array}$ & $0 / 23(0 \%)$ & $23 / 23(100 \%)$ \\
Human amniotic fluids & $0 / 18(0 \%)$ & $18 / 18(100 \%)$ \\
Paired palatal shelves & & \\
Mouse amniotic fluids & $36 / 36(100 \%)$ & $0 / 36(0 \%)$ \\
Human amniotic fluids & $15 / 15(100 \%)$ & $0 / 15(0 \%)$ \\
\hline
\end{tabular}

Note. MEE cell disappearance in paired palatal shelves indicates palatal fusion. Mouse amniotic fluids used were taken from E14.0. Human amniotic fluids were from 15 or 20 weeks of gestation.

at various stages of MEE cell disappearance, including the transient formation and disappearance of epithelial triangles and islets. Since the differentiation patterns of MEE cells in the cultured single palatal shelf is similar to that observed during palatal fusion (Mori et al., 1994; Martínez-Álvarez et al., 2000), it is clear that terminal differentiation of MEE cells is not necessarily dependent on palatal shelf contact and midline seam formation in vitro(Fig. 7). In addition, we found the inhibitory effects of mouse and human amniotic fluids on MEE cell differentiation, although promotive effects of the fluid on palatal fusion were previously suggested (Pourtois, 1968; Goss, 1976; Nanda et al., 1977). EGF and TIMPs (tissue inhibitors of matrix metalloproteinases) may be intrauterine epigenetic modifiers for MEE cell differentiation, because they are contained in amniotic fluid (Sundell et al., 1980; Murphy et al., 1981; Bunning et al., 1984; Kelly, et al., 1997) and can inhibit MEE cell disappearance in the fusing palate in vitro (Dixon and Ferguson, 1992; Blavier et al., 2001; Yamamoto et al., 2003). However, since amniotic fluid could prevent MEE cell differentiation only when the MEE was exposed directly to the fluid, palatal shelf contact and midline seam formation are prerequisite for MEE cell differentiation as well as palatal fusion to occur in utero (Fig. 7). Thus, our results are consistent with the previous observations that in the case of cleft palate, MEE cells of unfused palatal shelves never disappeared in utero, even when they appeared to retain the ability to differentiate and accomplish palatal fusion (Takagi etal., 2000; Lavrin etal., 2001; Zhang et al., 2002; Ito et al., 2003).

\section{The differentiation and behavior of MEE cells in single palatal shelf suspension culture}

In our culture system, such autonomous differentiation of MEE cells in the single palatal shelf enabled us to examine the differentiation and behavior of MEE cells more carefully than in the fusing palate, where MEE cells cannot be observed directly. It has been suggested that periderm cells of the MEE die or slough off to allow bilateral basal MEEs to adhere with each other (Fitchett and Hay, 1989). However, our SEM analysis revealed that most periderm cells do not die but become fibroblastic and actively migrate toward the oral and nasal sides at the early stage of MEE cell differentiation. These living periderm cells and their migration seem to be required for epithelial adhesion of the bilateral palatal shelves at the early stage of midline seam formation (Gato et al., 2002; Tudela et al., 2002) as well as transient formation of epithelial triangles during midline seam disruption (Carette and Ferguson, 1992).

Our study showed that cytokeratin-negative basal MEE cells actively pushed and disrupted their basement membrane during MEE cell differentiation. These findings suggest that the basal MEE cells transform into mesenchymal cells before the basement membrane is completely disrupted, because the loss of cytokeratin in the MEE and cell motility toward the mesenchyme are both indicative of EMT of MEE cells (Fitchett and Hay, 1989; Shuler et al., 1991, 1992; Griffith and Hay, 1992). In comparison with the loss of cytokeratin, we consider that expression of vimentin and fibroblast-like morphology are not sufficient evidence of EMT, since all MEE cells, including the cells forming epithelial triangles and islets, express vimentin simultaneously with cytokeratin

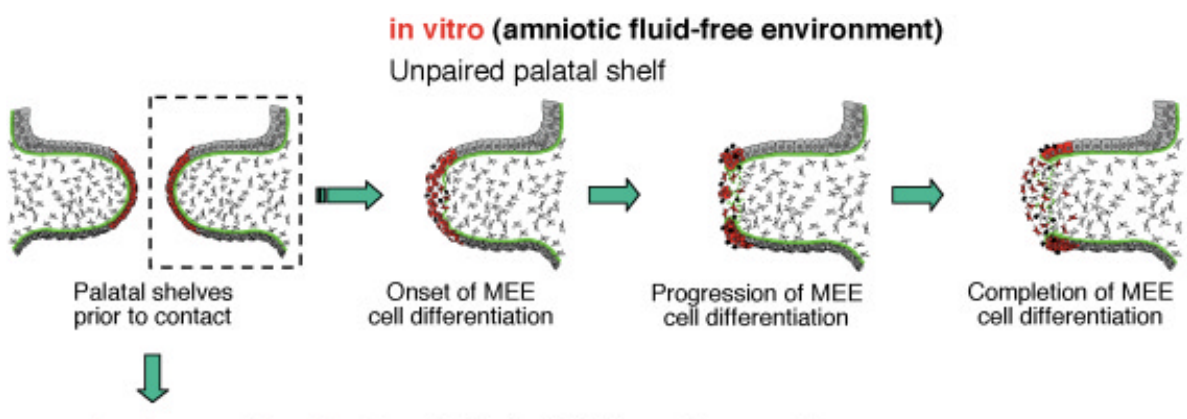

in utero and in vitro (amniotic fluid-rich environment)

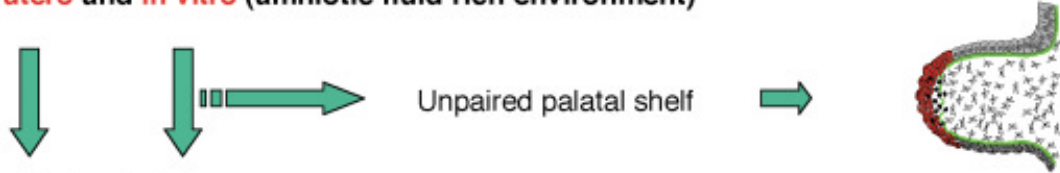

Paired palatal shelves

Persistence of the MEE

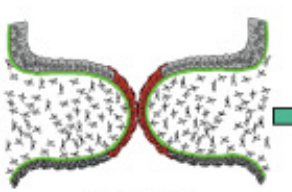

Contact of palatal shelves

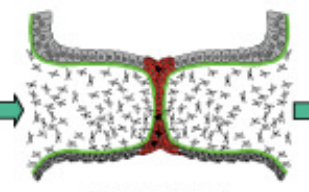

Formation of the MEE seam

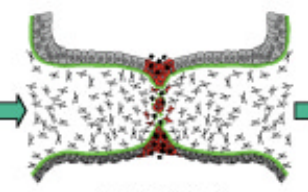

Disruption of the MEE seam

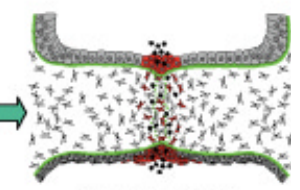

Mesenchymal confluence
Fig. 7. Summary diagram illustrating the process of MEE cell disappearance in the single palatal shelf grown in vitro with or without amniotic fluid and the palatal fusion process in utero. In the amniotic fluid-free environment such as in vitro, MEE cells can disappear from the medial edge of the single palatal shelf by means of apoptosis, epithelial-mesenchymal transformation and epithelial cell migration toward the oral and nasal epithelia, independently of palatal shelf contact and midline seam formation. However, in the amniotic fluid-rich environment in vitro and in utero, palatal shelf contact and midline epithelial seam formation are prerequisite for MEE cell differentiation as well as palatal fusion. Red cells represent MEE cells and MEE-derived cells; black cells represent dead cells; green lines and dots indicate the basement membrane and its fragments, respectively. 
throughout the disruption of the midline epithelial seam (Fitchett and Hay, 1989; Shuler et al., 1991; Gibbins et al., 1999). In addition, even the periderm cells become a fibroblast-like appearance during epithelial cell migration, as shown in this study, although the periderm cells of the MEE do not have the ability to undergo EMT (Fitchett and Hay, 1989). Such mesenchymal cytoskeleton and morphology appear to reflect the integrin-dependent adherence and migratory status of the MEE cells rather than EMT, because they can also be seen in wound edge epithelial cells during wound healing (SundarRaj et al., 1992; Gilles et al., 1999) and invasive cancer cells (Bernal and Stahel, 1985; Chu et al., 1996).

Our histological analyses further revealed that many transforming MEE cells underwent apoptosis during disruption of the basement membrane. Recently, Cuervo and Covarrubias (2004) proposed that the midline epithelial seam in the fusing palates disappears mainly via PCD, not via EMT. They claimed that MEE cell death activates disruption of the basement membrane and coined the term 'cataptosis' for such a phenomenon. Contrary to their hypothesis, our observation strongly supports the older theory that transforming basal MEE cells disrupt their basement membrane to migrate into the underlying mesenchyme (Fitchett and Hay, 1989; Shuler et al., 1991, 1992; Griffith and Hay, 1992; Kaartinen et al., 1997; Blavier et al., 2001). However, many investigators who support the EMT theory have overlooked or ignored the occurrence of cell death in the basal MEE. Previous cell tracing studies seem to result in the misjudgment that the basal MEE cells labeled with fluorescent dyes all remain in the mesenchyme after palatal fusion by successful EMT, even though many of them died and were phagocytosed by healthy neighboring cells. In addition, cell labeling methods can be tricky, and some previous studies have caused controversies about MEE cell fates, as described in Introduction. Although Dil (Carette and Ferguson, 1992) and CCFSE (Griffith and Hay, 1992) have been suggested to be integrated into cell structures, our experience has shown that healthy MEE cells never uptake the dyes in suspension culture or almost completely exclude the dyes, like a 'dye exclusion assay' (data not shown). In the case of adenovirusmediated transfection of GFP gene, healthy periderm did not allow them to access to the basal MEE cells.

Cell death in the MEE during palatal fusion has been regarded to be an example of classical PCD, which is the mechanism responsible for deletion of the transient structures during ontogeny (Glücksman, 1951; Saunders, 1966; Shapiro and Sweney, 1969; Jacobson et al., 1997; Cuervo et al., 2002; Cuervo and Covarrubias, 2004). However, our findings described above emphasize the possibility that the cell death may be secondarily caused by loss of the cells' adherent substrates. Currently, such cell death is widely known as 'anoikis' (Frisch and Francis, 1994). By now, it has been reported that anoikis occurs during mammary gland involution in female mice (Boudreau et al., 1995; Pullan et al., 1996) and Müllerian duct regression in embryonic male mice (Roberts et al., 2002). In the case of palatal MEE cells, the cells seem to develop greater matrix-dependency for survival and become sensitive to anoikis during EMT, because EMT is always associated with integrin-mediated cell scattering on the substrates, defined by the loss of intercellular junctions and acquisition of cell motility (Hay, 1995; Boyer et al., 2000). Recently, Blavier et al. (2001) and Brown et al. (2002) showed that the activity of MMPs (matrix metalloproteinases) is indispensable for disappearance of the MEE seam and disruption of its basement membrane during palatal fusion, and that at least MT1-MMP MMP-13, and MMP-3 are expressed in the MEE at the time of midline seam disruption. These MMPs are known to digest not only type IV collagen and laminins of basement membrane but also a variety of other extracellular matrix components, such as fibronectin, type I and III collagens, and proteoglycans (Werb, 1997; Seiki, 2003). In addition, MT1-MMP and MMP-3 also act as a shedase for E-cadherin by cleaving its extracellular domain (Noë etal., 2001; Rozanov etal., 2004). Therefore, it is most likely that while transforming MEE cells disrupt the underlying basement membrane and their cell-cell contact by using MMPs, the increasing MMP activity in the MEE can selectively kill the cells themselves owing to the extensive proteolysis of their stable scaffolding. Such cell death may also involve the migrating periderm cells because of their matrix-dependent status, though the neighboring native fibroblasts may be resistant to 'anoikis' (Frisch and Francis, 1994; McGill et al., 1997). In the true sense of anoikis, cell death in the MEE does not necessarily mean a genetically determined cell destiny but rather occurs accidentally during MEE cell differentiation, although it must be 'programmed' because of being predictable spatially and temporally. This concept of MEE cell death is further supported by our recent evidence that the midline epithelial seam of the fusing mouse plates can disappear in the absence of MEE cell death (Takahara etal., 2004).

\section{What is the most suitable method for palate culture?}

In other respects as well, it should be noted that our results are inconsistent with the previous hypotheses such as: (1) formation of the midline seam is indispensable for inducing EMT of basal MEE cells (Griffith and Hay, 1992; Sun et al., 1998), (2) basal MEE cells do not undergo PCD (Fitchett and Hay, 1989; Griffith and Hay, 1992), (3) MEE cells do not undergo EMT (Carette and Ferguson, 1992; Cuervo et al., 2002; Cuervo and Covarrubias, 2004), and (4) PCD is not activated in MEE cells unless palatal shelves make contact (Cuervo et al., 2002). Interestingly, most of the conflicting previous hypotheses cited above were also drawn from in vitro studies using rodent fetal palates. However, we cannot compare the results of the previous in vitro studies using mice and our present study simply, because those previous in vitrostudies are different from each other and from our present study in several points, including (1) mouse strains, (2) culture methods, (3) culture conditions (medium and gas), (4) gestational days of mice used for palate culture, and (5) cultivation times. The difference in these points may have caused the conflicting results, but this possibility has been unproven.

In this study, we further attempted to ascertain the cause of the conflicting results between the previous and our in vitro studies. Except for rats and mutant mice, Swiss-albino mice (SwissWebster, ICR, CD-1) have been most generally used to investigate the mechanisms underlying mammalian palatogenesis (Shuler et al., 1991, 1992; Griffith and Hay, 1992; MartínezÁlvarez etal., 2000; Cuervo etal., 2002; Cuervo and Covarrubias, 2004; Takahara et al., 2004). Since we obtained similar results using CD-1 mice (Charles River Japan Inc.), the ability of MEE cells to differentiate independently of palatal shelf contact and midline seam formation appears to be common at least in Swissalbino mice. However, such ability of MEE cells to differentiate may vary in other mouse strains and should be examined by using our single palatal shelf suspension culture. In addition, we tested the single palatal shelf of E13.5 ICR mice and confirmed that the MEE cells could disappear by $42-56$ hours in suspension culture 
in a similar manner to those of E14.0 palatal shelves. Therefore, the use of Swiss-albino mice of different colonies and/or somewhat different stages of fetal mouse palates is unlikely to be a fundamental cause of the conflicting results between the previous and our in vitro studies.

Rather, our results strongly suggest that one cause of the conflicting previous hypotheses of MEE cell differentiation is the culture environment of static cultures in a standard $\mathrm{CO}_{2}$ incubator. Effects of oxygen on palatal MEE cells have been underestimated and most of the previous in vitro studies have used static culture methods with a standard $\mathrm{CO}_{2}$ incubator for palate culture. However, our study has clearly shown the poor ability of MEE cells to differentiate in static culture with $95 \%$ air $/ 5 \% \mathrm{CO}_{2}$, indicating that the longstanding culture methods using a $\mathrm{CO}_{2}$ incubator is not suitable for palate culture. In contrast, in suspension culture with $95 \% \mathrm{O}_{2} / 5 \% \mathrm{CO}_{2}$, MEE cells could differentiate and disappear from the entire medial edge with perfect reproducibility. Furthermore, we found that BGJb medium is more suitable for palate organ culture than DMEM and DMEM/F12 (1:1 mixture) without further supplementation. According to the manufacturer's information, BGJb medium contains glucose and amino acids at much higher concentrations than those in DMEM and $\mathrm{DMEM} / \mathrm{F}-12$. These results indicate that palatal tissues, including MEE cells, are metabolically very active and require rich oxygen and nutrients for growth and differentiation. Since the developing fetus in utero is supported by maternally-derived oxygen and nutrients via placental and fetal circulatory systems, fetal explants grown in vitro should require a high concentration of oxygen and a nutrient-rich medium to support their growth and differentiation.

Taking these facts together, we regard the suspension culture with $95 \% \mathrm{O}_{2} / 5 \% \mathrm{CO}_{2}$ and BGJb medium as most suitable for growing fetal rodent palates in vitro. If artificially forced contact of palatal shelves is needed, static culture with $95 \% \mathrm{O}_{2} / 5 \% \mathrm{CO}_{2}$ seems to be more suitable than that with $95 \%$ air $/ 5 \% \mathrm{CO}_{2}$ to obtain reliable results. In addition, the MEE cell disappearance is unlikely to occur in utero by the effects of amniotic fluid. However, since the MEE cells of the cultured single palatal shelf showed similar differentiation patterns as observed in the palatal fusion process in utero, the MEE cell disappearance seems to reflect the ability of MEE cells to differentiate in the suitable culture conditions but is not an artifact. Thus, our present study is the first that clearly demonstrated the effects of various culture conditions (culture methods, oxygen concentrations, and amniotic fluid) on palatal MEE cell differentiation, which helps to understand the difference in cell differentiation in vitro and in utero.

Cleft palate is induced in laboratory mammals by a variety of teratogens and gene mutations, and the mechanisms of cleft palate formation must be heterogeneous. Our palate culture system is of a potential value for elucidating the mechanisms of normal and abnormal palatogenesis in mammalian fetuses.

\section{Materials and Methods}

\footnotetext{
Animals

Mature female ICR mice (Japan SLC Inc., Shizuoka, Japan) were mated overnight with a male, and noon of the day on which a vaginal plug was found was designated as day 0.5 of development (E0.5). Pregnant females were sacrificed by cervical dislocation on day 14.0 of gestation (E14.0) and the fetuses were removed from the uterus. All animal experiments in this study were performed in accordance with the principles of laboratory animal care at the Graduate School of Medicine, Kyoto University, and were approved by its animal research committee.
}

\section{Amniotic fluids}

E14.0 fetuses in the intact amniotic sac were aseptically removed from the uterus. The amniotic sac was punctured with the sharpened tip of tweezers and the amniotic fluid was carefully collected with a syringe, avoiding contamination with blood. Human amniotic fluids were collected in 2 cases of therapeutic abortion between 15 and 20 weeks of gestation with informed consent obtained from each patient in advance. The amniotic fluids were immediately cleared by centrifugation at $10,000 \mathrm{Xg}$ for 20 minutes at $4^{\circ} \mathrm{C}$ and stored at $-20^{\circ} \mathrm{C}$ until use.

\section{Palate organ cultures}

The maxillary portion was removed from each fetus by making two horizontal incisions through the head at the levels of the eye and oral angle. The left or right palatal shelf was further removed from each maxilla and was used as the single palatal shelf. The explants were cultured according to the suspension culture method (Shiota et al., 1990; Takahara et al., 2004). Briefly, five to seven explants were put into a bottle with BGJb medium (Invitrogen) containing 1\% penicillin/ streptomycin (Invitrogen) (1 $\mathrm{ml} /$ explant) and flushed for 2 min with a gas-mixture of $95 \% \mathrm{O}_{2} / 5 \% \mathrm{CO}_{2}$ or $95 \%$ air $/ 5 \% \mathrm{CO}_{2}$, and sealed air-tight. The bottles were incubated at $37^{\circ} \mathrm{C}$ on a roller device at $25-30 \mathrm{rpm}$ for up to 36 hours.

To determine whether MEE cells can differentiate using a static culture method, single palatal shelves were placed at the medium/air interface on a metal grid-supported Millipore filter in a dish, so that their nasal sides faced the filter. They were cultured for up to 72 hours with BGJb medium at $37^{\circ} \mathrm{C}$ in humidified $95 \%$ air $/ 5 \% \mathrm{CO}_{2}$ using a standard $\mathrm{CO}_{2}$ incubator or in humidified $95 \% \mathrm{O}_{2} / 5 \% \mathrm{CO}_{2}$ using an original culture chamber. The medium was changed one time at 36 hours of culture.

To examine the effects of human and mouse amniotic fluids on MEE cells and palatal fusion, single and paired palatal shelves were prepared from a given litter and cultured with the fluids diluted with BGJb medium to the concentration of $80 \%(\mathrm{v} / \mathrm{v})$ by using a suspension culture with $95 \%$ $\mathrm{O}_{2} / 5 \% \mathrm{CO}_{2}$ for up to 36 hours.

\section{Scanning electron microscopy (SEM)}

For SEM observation, the cultured explants were fixed with PLP-GA (periodate-lysine-paraformaldehyde-fixative containing 2.5\% glutaraldehyde) at $4^{\circ} \mathrm{C}$ for $3-5$ days. After post-fixation with $1 \% \mathrm{OsO}_{4}$ for 3 hours, they were dehydrated, dried, and coated with a thin layer of gold. The specimens were examined with a Hitachi S-430 scanning electron microscope (Hitachi, Tokyo, Japan).

\section{Histological analysis}

The palatal shelves after culture were fixed in $4 \%$ paraformaldehyde buffered with $0.1 \mathrm{M}$ sodium phosphate ( $\mathrm{pH} 7.4)$, embedded in paraffin, and serially sectioned ( $5 \mu \mathrm{m}$ thick). Sections taken at every $25 \mu \mathrm{m}$ were stained with hematoxylin and eosin for routine histology. Other sections were examined by dual immunofluorescent staining for cytokeratin with mouse monoclonal antibody, clone AE1+AE3 (DAKO), and for type IV collagen with rabbit polyclonal antibody (LSL, Tokyo, Japan), or by the combination of immunofluorescence and the TUNEL method (Gavrieli et al., 1992), as previously described (Mori et al., 1994; Takahara et al., 2004). Immunoproducts were visualized with a secondary antibody conjugated with FITC (fluorescein isothiocyanate) or TRITC (tetramethylrhodamine isothiocyanate). TUNEL-positive nuclei were visualized with avidin-conjugated FITC. Total nuclei of the sections were counter-stained with Hoechst 33342 (Sigma). All the sections were examined with an Axiophoto II (Carl Zeiss) fluorescent microscope.

\section{Acknowledgements}

We thank Ms. Keiko Okamoto for assistance in scanning electron microscopy. This study was supported by Grants-in-aid for Scientific Research from the Japanese Ministry of Education, Science, Sports, Technology and Culture. 


\section{References}

BERNAL, S.D. and STAHEL, R.A. (1985). Cytoskeleton-associated proteins: their role as cellular integrators in the neoplastic process. Crit. Rev. Oncol. Hematol. 3: 191-204.

BLAVIER, L., LAZARYEV, A., GROFFEN, J., HEISTERKAMP, N., DECLERCK, Y.A. and KAARTINEN, V. (2001). TGF-beta3-induced palatogenesis requires matrix metalloproteinases. Mol. Biol. Cel/12: 1457-1466.

BOUDREAU, N., SYMPSON, C.J., WERB, Z. and BISSELL, M.J. (1995). Suppression of ICE and apoptosis in mammary epithelial cells by extracellular matrix. Science 267: 891-893.

BOYER, B., VALLES, A.M. and EDME, N. (2000). Induction and regulation of epithelial-mesenchymal transitions. Biochem. Pharmacol. 60: 1091-1099.

BROWN, N.L., YARRAM, S.J, MANSELL, J.P. and SANDY, J.R. (2002). Matrix metalloproteinases have a role in palatogenesis. J. Dent. Res. 81: 826-830.

BUNNING, R.A., MURPHY, G., KUMAR, S., PHILLIPS, P. and REYNOLDS, J.J. (1984). Metalloproteinase inhibitors from bovine cartilage and body fluids. Eur. J. Biochem. 139: 75-80.

CARETTE, M.J. and FERGUSON, M.W. (1992). The fate of medial edge epithelial cells during palatal fusion in vitro: an analysis by Dil labelling and confocal microscopy. Development 114: 379-388.

CHU, Y.W., SEFTOR, E.A., ROMER, L.H. and HENDRIX, M.J. (1996). Experimental coexpression of vimentin and keratin intermediate filaments in human melanoma cells augments motility. Am. J. Pathol. 148: 63-69.

CUERVO, R., VALENCIA, C., CHANDRARATNA, R.A. and COVARRUBIAS, L. (2002). Programmed cell death is required for palate shelf fusion and is regulated by retinoic acid. Dev. Biol. 245: 145-156.

CUERVO, R. and COVARRUBIAS, L. (2004). Death is the major fate of medial edge epithelial cells and the cause of basal lamina degradation during palatogenesis. Development 131: 15-24.

DIXON, M.J. and FERGUSON, M.W. (1992). The effects of epidermal growth factor, transforming growth factors alpha and beta and platelet-derived growth factor on murine palatal shelves in organ culture. Arch. Oral Biol. 37: 395-410.

FERGUSON, M.W. (1988). Palate development. Development 103: 41-60.

FITCHETT, J.E. and HAY, E.D. (1989). Medial edge epithelium transforms to mesenchyme after embryonic palatal shelves fuse. Dev. Biol. 131: 455-474.

FRISCH, S.M. and FRANCIS, H. (1994). Disruption of epithelial cell-matrix interactions induces apoptosis. J. Cell Biol. 124: 619-626.

GATO, A., MARTINEZ, M.L., TUDELA, C., ALONSO, I., MORO, J.A., FORMOSO, M.A., FERGUSON, M.W. and MARTÍNEZ-ÁLVAREZ, C. (2002). TGF-beta(3)induced chondroitin sulphate proteoglycan mediates palatal shelf adhesion. Dev. Biol. 250: 393-405.

GIBBINS, J.R., MANTHEY, A., TAZAWA, Y.M., SCOTT, B., BLOCH-ZUPAN, A. and HUNTER, N. (1999). Midline fusion in the formation of the secondary palate anticipated by upregulation of keratin $\mathrm{K} 5 / 6$ and localized expression of vimentin mRNA in medial edge epithelium. Int. J. Dev. Biol. 43: 237-244.

GILLES, C., POLETTE, M., ZAHM, J.M., TOURNIER, J.M., VOLDERS, L., FOIDART, J.M. and BIREMBAUT, P. (1999). Vimentin contributes to human mammary epithelial cell migration. J. Cel/ Sci. 112: 4615-4625.

GLÜCKSMANN, A. (1951). Cell death in normal vartebrate ontogeny. Biol. Rev. 26: 59-86.

GOSS, A.N. (1976). Amniotic fluid and rat palatal fusion in vitro. Arch. Oral Biol. 21: 631-632.

GRIFFITH, C.M. and HAY, E.D. (1992). Epithelial-mesenchymal transformation during palatal fusion: carboxyfluorescein traces cells at light and electron microscopic levels. Development 116: 1087-1099.

HAY, E.D. (1995). An overview of epithelio-mesenchymal transformation. Acta Anat. (Basel). 154: 8-20.

ITO, Y., YEO, J.Y., CHYTIL, A., HAN, J., BRINGAS, P.Jr., NAKAJIMA, A., SHULER, C.F., MOSES, H.L. and CHAI, Y. (2003). Conditional inactivation of Tgfbr2 in cranial neural crest causes cleft palate and calvaria defects. Development 130 : 5269-5280.

JACOBSON, M.D., WEIL, M. and RAFF, M.C. (1997). Programmed cell death in animal development. Cel/88: 347-354.
KAARTINEN, V., CUI, X.M., HEISTERKAMP, N., GROFFEN, J. and SHULER, C.F (1997). Transforming growth factor-beta 3 regulates transdifferentiation of medial edge epithelium during palatal fusion and associated degradation of the basement membrane. Dev. Dyn. 209: 255-260.

KELLY, E.J., NEWELL, S.J., BROWNLEE, K.G., FARMERY, S.M., CULLINANE, C REID, W.A., JACKSON, P., GRAY, S.F., PRIMROSE, J.N. and LAGOPOULOS, M. (1997). Role of epidermal growth factor and transforming growth factor alpha in the developing stomach. Arch. Dis. Child Fetal Neonatal. Ed. 76: 158-162.

LAVRIN, I.O., MCLEAN, W., SEEGMILLER, R.E., OLSEN, B.R. and HAY, E.D. (2001). The mechanism of palatal clefting in the Col11a1 mutant mouse. Arch. Oral Biol. 46: 865-869.

MARTÍNEZ-ÁLVAREZ, C., TUDELA, C., PÉREZ-MIGUELSANZ, J., O'KANE, S., PUERTA, J. and FERGUSON, M.W. (2000). Medial edge epithelial cell fate during palatal fusion. Dev. Biol. 220: 343-357.

MCGILL, G., SHIMAMURA, A., BATES, R.C., SAVAGE, R.E. and FISHER, D.E. (1997). Loss of matrix adhesion triggers rapid transformation-selective apoptosis in fibroblasts. J. Cel/ Biol. 138: 901-911.

MORI, C., NAKAMURA, N., OKAMOTO, Y., OSAWA, M. and SHIOTA, K. (1994). Cytochemical identification of programmed cell death in the fusing fetal mouse palate by specific labelling of DNA fragmentation. Anat. Embryol. (Berl). 190: 2128.

MURPHY, G., CAWSTON, T.E. and REYNOLDS, J.J. (1981). An inhibitor of collagenase from human amniotic fluid. Purification, characterization and action on metalloproteinases. Biochem. J. 195: 167-170.

NANDA, R., MAY, D.L. and LITE, S. (1977). The role of amniotic fluid on the in-vitro palatal fusion of normal and vitamin A-treated rat foetuses. Arch. Oral Biol. 22 613-618.

NOË, V., FINGLETON, B., JACOBS, K., CRAWFORD, H.C., VERMEULEN, S. STEELANT, W., BRUYNEEL, E., MATRISIAN, L.M. and MAREEL, M. (2001). Release of an invasion promoter E-cadherin fragment by matrilysin and stromelysin1. J. Cel/ Sci. 114: 111-118.

POURTOIS, M. (1966). Onset of the acquired potentiality for fusion in the palatal shelves of rats. J. Embryol. Exp. Morphol. 16: 171-182.

POURTOIS, M. (1968). Amniotic fluid and palatal fusion in the rat. Arch. Oral Biol. 13: 87-92

PULLAN, S., WILSON, J., METCALFE, A., EDWARDS, G.M., GOBERDHAN, N., TILLY, J., HICKMAN, J.A., DIVE, C. and STREULI, C.H. (1996). Requirement of basement membrane for the suppression of programmed cell death in mammary epithelium. J. Cel/ Sci. 109: 631-642.

ROBERTS, L.M., VISSER, J.A. and INGRAHAM, H.A. (2002). Involvement of a matrix metalloproteinase in MIS-induced cell death during urogenital development. Development 129: 1487-1496.

ROZANOV, D.V., DERYUGINA, E.I., MONOSOV, E.Z., MARCHENKO, N.D. and STRONGIN, A.Y. (2004). Aberrant, persistent inclusion into lipid rafts limits the tumorigenic function of membrane type-1 matrix metalloproteinase in malignant cells. Exp. Cell Res. 293: 81-95.

SAUNDERS, J.W.JR. (1966). Death in embryonic systems. Science 154: 604-612.

SEIKI, M. (2003). Membrane-type 1 matrix metalloproteinase: a key enzyme for tumor invasion. Cancer Lett. 194: 1-11.

SHAPIRO, B.L. and SWENEY, L. (1969). Electron microscopic and histochemical examination of oral epithelial-mesenchymal interaction (programmed cell death). J. Dent. Res. 48: 652-660.

SHIOTA, K., KOSAZUMA, T., KLUG, S. and NEUBERT, D. (1990). Development of the fetal mouse palate in suspension organ culture. Acta Anat. (Basel). 137: 5964.

SHULER, C.F., GUO, Y., MAJUMDER, A. and LUO, R.Y. (1991). Molecular and morphologic changes during the epithelial-mesenchymal transformation of palatal shelf medial edge epithelium in vitro. Int. J. Dev. Biol. 35: 463-472.

SHULER, C.F., HALPERN, D.E., GUO, Y. and SANK, A.C. (1992). Medial edge epithelium fate traced by cell lineage analysis during epithelial-mesenchymal transformation in vivo. Dev. Biol. 154: 318-330.

SMILEY, G.R. and KOCH, W.E. (1971). Fine structure of mouse secondary palate development in vitro. J. Dent. Res. 50: 1671-1677.

SMILEY, G.R. and KOCH, W.E. (1972). An in vitro and in vivo study of single palatal processes. Anat. Rec. 173: 405-415. 
SMILEY, G.R. and KOCH, W.E. (1975). A comparison of secondary palate development with different in vitro techniques. Anat. Rec. 181: 711-723.

SUN, D., VANDERBURG, C.R., ODIERNA, G.S. and HAY, E.D. (1998). TGFbeta3 promotes transformation of chicken palate medial edge epithelium to mesenchyme in vitro. Development 125: 95-105

SUNDARRAJ, N., RIZZO, J.D., ANDERSON, S.C. and GESIOTTO, J.P. (1992). Expression of vimentin by rabbit corneal epithelial cells during wound repair. Cell Tissue Res. 267: 347-356.

SUNDELL, H.W., GRAY, M.E., SERENIUS, F.S., ESCOBEDO, M.B. and STAHLMAN, M.T. (1980). Effects of epidermal growth factor on lung maturation in fetal lambs. Am. J. Pathol. 100: 707-725.

TAKAGI, T.N., MATSUI, K.A., YAMASHITA, K., OHMORI, H. and YASUDA, M. (2000). Pathogenesis of cleft palate in mouse embryos exposed to $2,3,7$, 8tetrachlorodibenzo-p-dioxin (TCDD). Teratog. Carcinog. Mutagen. 20: 73-86.

TAKAHARA, S., TAKIGAWA, T. and SHIOTA, K. (2004). Programmed cell death is not a necessary prerequisite for fusion of the fetal mouse palate. Int. J. Dev. Biol. 48: 39-46.

TANIGUCHI, K., SATO, N. and UCHIYAMA, Y. (1995). Apoptosis and heterophagy of medial edge epithelial cells of the secondary palatine shelves during fusion. Arch. Histol. Cytol. 58: 191-203.
TUDELA, C., FORMOSO, M-A., MARTÍNEZ, T., PÉREZ, R., APARICIO, M., MAESTRO, C., DEL RÍO, A., MARTÍNEZ, E., FERGUSON, M. and MARTÍNEZÁLVAREZ, C. (2002). TGF-beta3 is required for the adhesion and intercalation of medial edge epithelial cells during palate fusion. Int. J. Dev. Biol. 46: 333-336.

WERB, Z. (1997). ECM and cell surface proteolysis: regulating cellular ecology. Cell 91: 439-442

YAMAMOTO, T., CUI X.M. and SHULER, C.F. (2003). Role of ERK1/2 signaling during EGF-induced inhibition of palatal fusion. Dev. Biol. 260: 512-521.

ZHANG, Z., SONG, Y., ZHAO, X., ZHANG, X., FERMIN, C. and CHEN, Y. (2002). Rescue of cleft palate in Msx1-deficient mice by transgenic Bmp4 reveals a network of BMP and Shh signaling in the regulation of mammalian palatogenesis. Development 129: 4135-4146.

Received: March 2004 Reviewed by Referees: April 2004 Modified by Authors and Accepted for Publication: May 2004

Edited by: Makoto Asashima 